\title{
Silk-Cocoon Matrix Immobilized Lipase Catalyzed Transesterification of Sunflower Oil for Production of Biodiesel
}

\author{
Sushovan Chatterjee, ${ }^{1}$ Dipti Yadav, ${ }^{2}$ Lepakshi Barbora, ${ }^{2}$ \\ Pinakeswar Mahanta, ${ }^{3}$ and Pranab Goswami ${ }^{4}$ \\ ${ }^{1}$ Department of Mechanical Engineering, National Institute of Technology Silchar, Silchar, Assam 788010, India \\ ${ }^{2}$ Centre for Energy, Indian Institute of Technology Guwahati, Guwahati, Assam 781039, India \\ ${ }^{3}$ Department of Mechanical Engineering, Indian Institute of Technology Guwahati, Guwahati, Assam 781039, India \\ ${ }^{4}$ Department of Biotechnology, Indian Institute of Technology Guwahati, Guwahati, Assam 781039, India
}

Correspondence should be addressed to Pranab Goswami; pgoswami@iitg.ernet.in

Received 23 September 2013; Revised 2 January 2014; Accepted 3 January 2014; Published 10 February 2014

Academic Editor: Vijay Bokade

Copyright (C) 2014 Sushovan Chatterjee et al. This is an open access article distributed under the Creative Commons Attribution License, which permits unrestricted use, distribution, and reproduction in any medium, provided the original work is properly cited.

Biodiesel from sunflower oil using lipase chemically immobilized on silk-cocoon matrix in a packed-bed bioreactor was investigated. The immobilization was demonstrated by field-emission scanning electron microscopy and activity study. The lipase loading was $738.74 \mathrm{U}$ ( $\sim 0.01 \mathrm{~g}$ lipase powder)/g-lipase-immobilized matrix. The $\mathrm{K}_{\mathrm{m}}$ (Michaelis-Menten constant) of the free and the immobilized lipase was $451.26 \mu \mathrm{M}$ and $257.26 \mu \mathrm{M}$, respectively. Low $\mathrm{K}_{\mathrm{m}}$ value of the immobilized lipase is attributed to the hydrophobic nature of the matrix that facilitated the substrate diffusion to the enzyme surface. The biodiesel yield of $81.62 \%$ was obtained at 48 hours reaction time, $6: 1$ methanol : oil ratio $(\mathrm{v} / \mathrm{v})$, and $30^{\circ} \mathrm{C}$. The immobilized lipase showed high operational stability at $30^{\circ} \mathrm{C}$. The substrate conversion was only marginally decreased till third cycle (each of 48 hours duration) of the reaction since less than even $5 \%$ of the original activity was decreased in each of the second and third cycle. The findings demonstrated the potential of the silk-cocoon as lipase immobilization matrix for industrial production of biodiesel.

\section{Introduction}

Lipase catalyzed transesterification has received renewed interest over the conventional transesterification processes in recent era because of room temperature reaction condition, reuse of catalysts, ability to esterify both glycerides and free fatty acids in single step, and production of glycerol stream with minimal water content and little or no inorganic material [1]. However, the cost of the lipase is one of the major obstacles in developing lipase-based process for the commercial applications. Application of immobilized lipase in biocatalytic processes substantially averts the cost factor, thus contributing to the economic viability of the process for commercial applications [2]. The immobilization, however, should not affect the functional activity and stability of the lipase being used as catalyst for the transesterification reaction. The role of the immobilizing support material is therefore critical for the success of the transesterification process. Application of various lipase immobilization support matrices for biodiesel production has been reported with mixed results [3, 4]. Recently, much attention has been paid to utilize biocompatible materials for the immobilization of lipase to overcome the loss of lipase stability commonly occurred due to the immobilization $[5,6]$. Another equally important factor that governs the functional activity and stability of the immobilized lipase is the kind of immobilizations. Different approaches such as, chemical cross-linking [7], encapsulation [8], and adsorption [9] have been utilized for immobilization of lipase on various support systems for the transesterification reaction. The success of such approaches, however, could not be convincingly generalized so far and showed variation across enzymes of different sources [10-15]. The additional important issue that needs to be considered for developing the biocatalytic process is an efficient bioreactor 
for facilitating the reaction to achieve high product yield. Different bioreactors for the lipase catalyzed transesterification of vegetable oil for the production of biodiesel have been reported such as, biphasic bioreactor [16], membrane bioreactor [17], packed-bed bioreactor [18], fluidized bed bioreactor [19], and stirrer tank bioreactor [20]. In this investigation we used silk cocoon as lipase immobilization matrix. The silkcocoon is proteinaceous, highly porous, biodegradable, and a renewable biomaterial. The material is locally available at a competitively low price. This paper describes the findings of our investigation on the transesterification of vegetable oil in a small scale packed-bed reactor using lipase-immobilized on silk cocoon, a novel material of biological origin.

\section{Materials and Methods}

2.1. Materials. Powdered lipase (73000 U/g) from Aspergillus niger (RM-1265) was obtained from Himedia Laboratory Pvt., Ltd., India. Sodium hydroxide, methanol, glutaraldehyde, and para nitrophenyl acetate (PNPA) were obtained from Merck, India. Sunflower oil (SFO) was procured from local market. Silk cocoons produced by Antheraea assama were purchased from Sualkuchi, the silk village of Assam, India.

2.2. Immobilization of Lipase. The lipase was immobilized in fibrous silk cocoon. For that the inner worms were removed first and then the outer shells were collected and boiled for 2 hours to remove any sort of dust and microbial contamination. The cleaned cocoons were dried under air at room temperature. Each dried cocoon was then cut vertically and horizontally into eight small nearly uniform pieces. The sliced pieces of cocoons (total 4.69 grams) were treated with alkali $(0.8 \mathrm{~N} \mathrm{NaOH})$ for 2 hours to remove gums and sericin (a protein) and then washed with methanol $(250 \mathrm{~mL})$ and double distilled water $(500 \mathrm{~mL})$. The cleaned sericin free cocoons were then treated with a mixture of equal volume of glutaraldehyde (5\%) and lipase solution ( $1 \mathrm{~g}$ powdered lipase in $50 \mathrm{~mL}$ of $0.1 \mathrm{M}$ sodium phosphate buffer of $\mathrm{pH} 7.2(\mathrm{SPB}))$ for 24 hours at room temperature. The lipase-immobilized cocoon pieces were then washed with the $50 \mathrm{mM}$ SPB followed by lyophilization for 8 hours to dryness and then kept at $4^{\circ} \mathrm{C}$ for further use.

2.3. Lipase Activity Assay. The activity of free and immobilized lipase was measured following a reported method using PNPA as a substrate with some minor modifications [21]. The activity of the enzyme was determined by measuring the absorption of the product $p$-nitrophenol formed in the solution at $410 \mathrm{~nm}$. The reaction mixture $(1.0 \mathrm{~mL})$ consists of $0.5 \mathrm{~mL} 100 \mathrm{mM}$ SPB, $2 \mathrm{mM}$-nitrophenyl acetate, $5 \%$ $\mathrm{CH}_{3} \mathrm{CN}$, and $0.25 \mathrm{~mL}$ of enzyme solution (powdered lipase in $0.1 \mathrm{M}$ SPB) or suitable amount of silk cocoon immobilizedlipase in $0.25 \mathrm{~mL} 100 \mathrm{mM}$ SPB. A control was run simultaneously using the same SPB. The reactions were initiated by adding $0.15 \mathrm{~mL}$ of $50 \mathrm{mM}$-nitrophenyl acetate (initially dissolved in dry $\mathrm{CH}_{3} \mathrm{CN}$ ) to the buffer solution containing the enzyme that was preincubated at $37^{\circ} \mathrm{C}$ for $3 \mathrm{~min}$. The mixture was then incubated for $2 \mathrm{~min}$ at $37^{\circ} \mathrm{C}$. The reaction was stopped by adding $1 \mathrm{~mL}$ acetone and then clarified at $10,000 \times \mathrm{g}$. The clear colored (pale yellow) solution was monitored for the formation of $p$-nitrophenol by measuring absorbance at $410 \mathrm{~nm}$. One unit of the lipase activity was defined as the amount of enzyme which liberates $1 \mu \mathrm{mol}$ of p-nitrophenol per min at $37^{\circ} \mathrm{C}$. Experiments were carried out in triplicate and the data were considered with standard error within $5 \%$ at a confidence level of 0.85 .

2.4. FESEM Analysis. The morphology of the silk-fiber on the cocoons surface before and after immobilization of lipase was studied by field-emission scanning electron microscopy (FESEM) (instrument model: ZEISS; made by Sigma, Germany). The sample was imaged by scanning with high-energy beam electrons at $20 \mathrm{keV}$ in a raster scan pattern. The sliced dry silk cocoons, which are nonconducting in nature, were initially coated with gold under vacuum. The dry specimens were then mounted on a specimen stub using an adhesive electrically-conductive double-sided adhesive tape.

2.5. Bioreactor for Transesterification of Sunflower Oil. The bioreactor used for the transesterification reaction is shown in Figure 1. Lipase-immobilized cocoons were packed in the column under normal atmospheric pressure and room temperature $\left(25^{\circ} \mathrm{C}\right)$. Total volume of the packed-bed column was $37.17 \mathrm{~mL}$, packed volume was $23.36 \mathrm{~mL}$, and void volume was $13.81 \mathrm{~mL}$. Above the packed column, nearly $10 \mathrm{~mL}$ space was left for retention and recirculation of the reaction mixture. A mixture of methanol and sunflower oil $(250 \mathrm{~mL}$ in various ratios $\mathrm{v} / \mathrm{v}$ ) was sonicated in ultrasonic bath and taken in a three-necked round bottom glass container. Recirculation of the reaction mixture through the glass column containing silk-cocoon immobilized lipase was facilitated by means of a peristaltic pump (made by Miclins; model no.: PP20) at an optimized flow rate of $1.6 \mathrm{~mL} \mathrm{~min}^{-1}$. Continuous mixing of the oil-alcohol was confirmed by magnetic stirrer. The temperature of the water jacket was maintained by connecting the inlet and outlet terminals of the jacket to a digital temperature controlled water bath (made by Thermo Haake; model no: P5) with temperature range $5-95^{\circ} \mathrm{C}$.

2.6. Product Analysis. The transesterification of sunflower oil for the production of biodiesel was carried out in the bioreactor containing lipase-immobilized cocoon matrix. The reaction was carried out at $30^{\circ} \mathrm{C}$ using reservoir substrate concentration of $25 \%(\mathrm{v} / \mathrm{v})$. Samples, each of $1 \mathrm{~mL}$, were withdrawn at different time intervals for gas-chromatographic analysis. The product was analyzed by injecting the sample in thermocapillary column (made by M/s Thermo Electron Corporation; model: TRACE TR-Wax MS) fitted on the gas chromatography equipment (made by Varian; model: CP3800 ). The column has an internal diameter of $0.25 \mathrm{~mm}$, film thickness of $0.25 \mu \mathrm{m}$, and length of $30 \mathrm{~m}$, with the phase type of polyethylene glycol. The parameters used in the analyses were carrier gas, nitrogen (flow rate $2 \mathrm{~mL} / \mathrm{min}$ ), detector, FID, injector temperature, $28^{\circ} \mathrm{C}$, and column and oven temperature, $230^{\circ} \mathrm{C}$. For identification of the product in the chromatogram, the standard methyl esters (Sigma, USA) as well as 


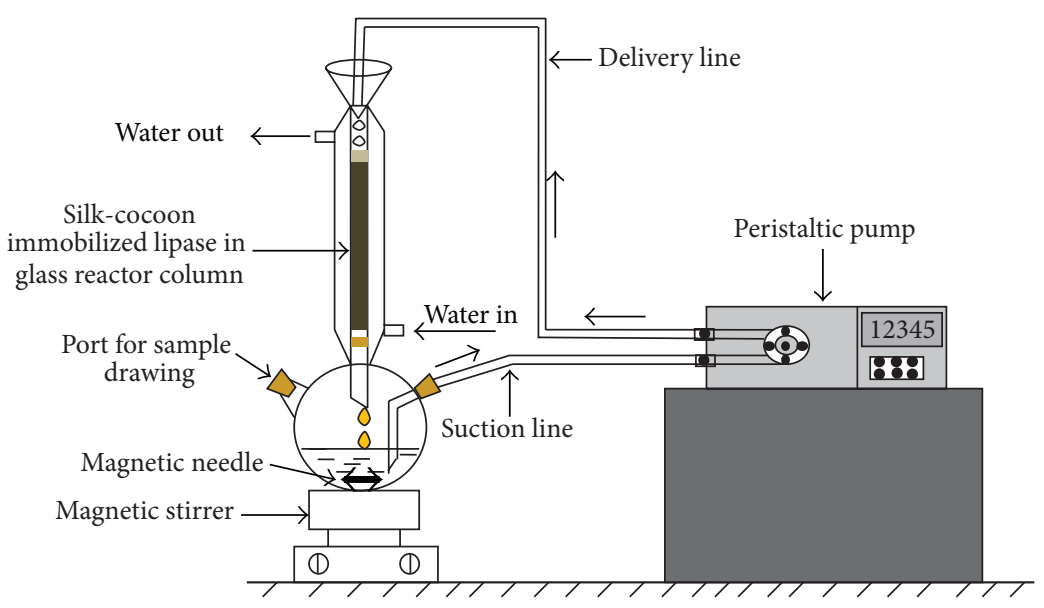

FIGURE 1: Bioreactor for silk-cocoon immobilized lipase catalyzed transesterification reaction for biodiesel production.

the pure methyl esters of the fatty acids produced chemically from sunflower oil using alkaline transesterification method were used. Based on the total area of the major methyl esters in the chromatogram the quantitative estimation and yield of the product were calculated. Although sunflower oil contains different fatty acids of varying chain lengths and different degree of unsaturation, yet it contains three major fatty acids, namely, linoleic acid (C 18:2), oleic acid (C 18:1), and palmitic acid (C 16:0) [22]. We have calculated the total area under the three major ester peaks that appeared in the chromatogram. In order to compare the wholesomeness of the methyl ester formed during biocatalytic transesterification of sunflower oil, pure methyl esters were initially prepared from sunflower oil using sodium hydroxide as catalyst.

$50 \mathrm{~mL}$ refined sunflower oil, $12.5 \mathrm{~mL}$ methanol, and 0.4 gram of anhydrous sodium hydroxide were mixed in a $250 \mathrm{~mL}$ Erlenmeyer flask sealed (air tight) with cork and kept in an orbital shaker at $150 \mathrm{rpm}$ and $55^{\circ} \mathrm{C}$ for 8 hours. The reaction mixture was then taken in a separating funnel and the bottom layer of glycerol was separated out. Unreacted methanol was separated by vacuum distillation at $65^{\circ} \mathrm{C}$ using vacuum rotary evaporator (model: Hahnvapour; made by $\mathrm{M} / \mathrm{s}$ Hahnshin Scientific Co.). The remaining liquid was washed four times with double distilled water by hand shaking in a separating funnel. The pure fatty acid methyl esters so obtained were dried by anhydrous sodium sulphate and kept in a glass bottle with airtight cork at $4^{\circ} \mathrm{C}$ for further use.

2.7. Statistics of Analysis. All the data presented in this study were the mean of three or more experiments with a variation within $10 \%$. Analysis of variance was carried out for the statistical data, at $P<0.05$ following a standard method [23]. When the experimental data value was found to be significant, critical difference was calculated by multiplying the standard error of difference with the corresponding error values at $5 \%$ level of probability. Significant differences among the means were determined by using least significant difference test.

\section{Results and Discussion}

3.1. Morphological Study of Lipase-Immobilized Silk-Cocoons. The silk cocoons used for lipase immobilization were ovular in shape and brown in colour as shown in Figure 2(a). The average length and diameter of the cocoons were $5 \mathrm{~cm}$ and $2 \mathrm{~cm}$, respectively. The average weight of the cocoon was $293.67 \mathrm{mg}$. The lipase was successfully immobilized into silk cocoons matrix using glutaraldehyde cross-linking which is evident from the FESEM images (Figure 2). Figures 2(b) and 2(c) show the FESEM images of the silk-cocoon fiber before and after immobilization of the lipase. Formation of white coating on the silk-fibers was observed after immobilization which were absent in the fibers of the native cocoons.

3.2. Lipase Loading Density and Kinetic Study of Immobilized Lipase. The activity of the loaded lipase was $738.74 \mathrm{U}$ ( $~ 0.01 \mathrm{~g}$ lipase powder)/g-lipase-immobilized cocoons. An average of $0.22 \mathrm{~g}$ lipase powder was immobilized per gram of dry cocoon. To determine the apparent Michaelis-Menten constant $\left(\mathrm{K}_{\mathrm{m}}^{\mathrm{app}}\right)$ of the free and immobilized lipase, the initial activity was measured with different concentrations of PNPA at optimum assay conditions of $37^{\circ} \mathrm{C}$ and $\mathrm{pH}$ 7.2. Using the Lineweaver-Burk plot, the $\mathrm{K}_{\mathrm{m}}^{\mathrm{app}}$ was determined to be $451.26 \mu \mathrm{M}$ and $257.26 \mu \mathrm{M}$, respectively for the free and immobilized lipase. The reason for the lower Km value of the immobilized lipase than the free lipase is attributed to the hydrophobic [24, 25] and porous [26] nature of the silk-cocoon matrix that provides nonaqueous environment for fast diffusion of the less polar substrates, sunflower oil and methanol, which resulted in effective enzyme-substrate interaction for the catalysis.

3.3. Analysis of Biodiesel Yield by Gas Chromatography. In this investigation sunflower oil was selected as the substrate for the transesterification reaction on the basis of the fact that the fuel properties of the methyl ester of the fatty acids obtained from the sunflower oil were nearly similar to those found in the petroleum diesel oil [27]. About 1.18 and 1.27 liters of methyl ester of fatty acids obtained from sunflower 


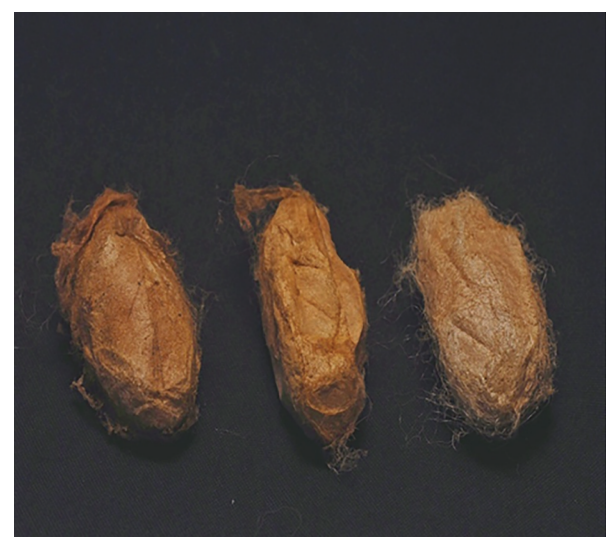

(a)

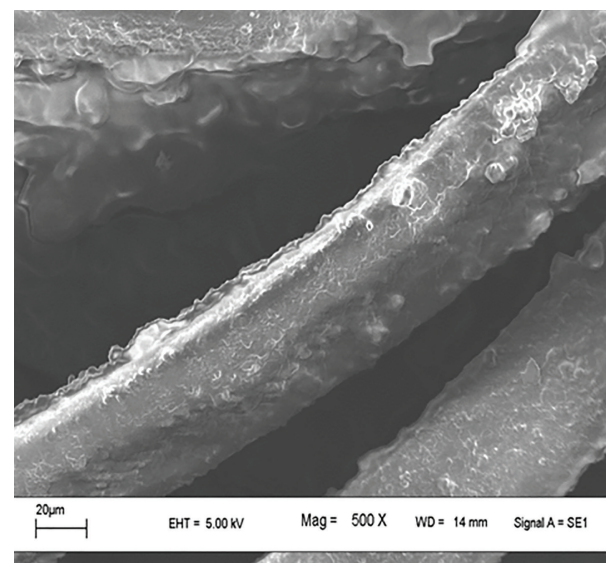

(b)

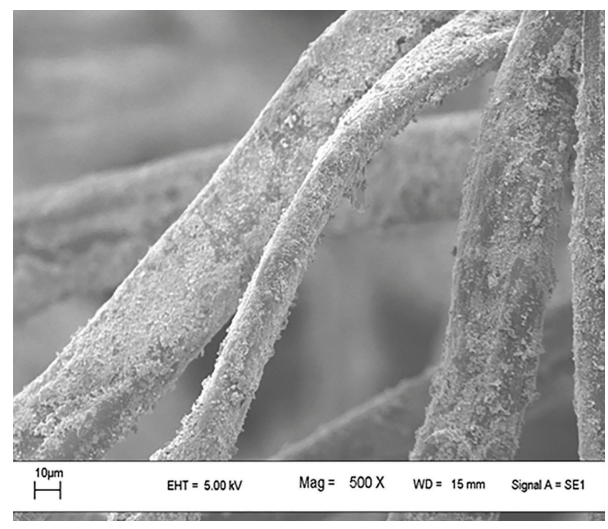

(c)

FIgURE 2: (a) Silk-cocoon from Antheraea assama. Image was captured by a camera (made by NIKON D 200) at F-50 mm. FESEM photograph (magnification: 500X) of silk-fiber of silk cocoons: (b) before lipase immobilization and (c) after lipase immobilization.

oil and castor oil, respectively, were required to produce the same energy as that generated by a liter of diesel [28]. The analysis of different ester content in biodiesel blends or esterified vegetable oil samples is a unique challenge due to complexity of the sample. However, gas chromatography has been efficiently used for easy analysis of methyl esters [29]. The major compounds formed with both alkali and
TABLE 1: Property of sunflower oil and its methyl ester.

\begin{tabular}{lcc}
\hline Property & $\begin{array}{c}\text { Sunflower } \\
\text { oil }\end{array}$ & $\begin{array}{c}\text { Methyl ester of } \\
\text { sunflower oil }\end{array}$ \\
\hline Specific gravity & 0.920 & 0.878 \\
Calorific value $(\mathrm{M}) / \mathrm{kg})$ & 39.57 & 40.56 \\
Viscosity $\left(\mathrm{mm}^{2} / \mathrm{s}\right)$ at $40^{\circ} \mathrm{C}$ & 4.914 & 4.5 \\
Flash point $\left({ }^{\circ} \mathrm{C}\right)$ & 318 & 85 \\
Cetane index & 35.8 & 46.9 \\
Cloud point $\left({ }^{\circ} \mathrm{C}\right)$ & 7.2 & 1.0 \\
\hline
\end{tabular}

lipase catalyzed transesterification reactions were the esters of palmitic acid (C 16:0), oleic acid (C 18:1), and linoleic acid (C 18:2). Moreover, the ratios of these esters formed in both transesterification reactions were also found to be nearly the same. It is known that the specificity of alkali catalysts for the acyl side chains in lipids during transesterification reaction is practically nil [12]. Hence, it may be inferred that palmitic acid, oleic acid, and linoleic acid are the predominant fatty acids present as acyl chains in the triacylglycerol constituent of the substrate sunflower oil used in this investigation. The percentages of linoleic acid, oleic acid, and palmitic acid present in the sunflower oil were $\sim 71.4, \sim 15.9$, and $\sim 5.8$, respectively [22]. The properties of the sunflower oil and its methyl ester are provided in Table 1. We compared the range of product formed during silk-cocoon immobilized lipase catalyzed transesterification reaction with the one formed during conventional alkali catalyzed transesterification reaction in gas chromatograms as shown in Figures 3(a) and 3(b). These findings also further implied that the quality of the methyl esters and hence the biodiesel formed during silk-cocoon immobilized lipase catalyzed transesterification reaction would be nearly similar to those obtained by conventional alkali catalyzed transesterification reaction. The conversion yield calculated was based on the relative conversion yield of the three major esters (i.e., the methyl esters of palmitic acid (C 16:0), oleic acid (C 18:1), and linoleic acid (C 18:2)) compared with the yield obtained by pure alkali catalyzed transesterification of sunflower oil. The yield obtained by using silk-cocoon immobilized lipase was found to be $86 \%$. We calculated the yield by considering that sodium hydroxide catalyzed transesterification of sunflower oil with methanol gives $100 \%$ yield. The alkali catalyzed transesterification reaction was carried out for extended time to ensure complete conversion of sunflower oil to biodiesel. Notably, a biodiesel yield of $97.1 \%$ using alkali catalyzed transesterification of sunflower oil has been reported [30].

\subsection{Optimization of Alcohol-Oil Ratio and Temperature} for Transesterification Reaction. Substrate conversion yields were studied at different methanol to sunflower oil ratio. The substrate conversion yields (\%) of $64.38,76.86,81.62$, and 76.51 were obtained at the corresponding methanol to sunflower oil ratio $(\mathrm{v} / \mathrm{v})$ of $2: 1,4: 1,6: 1$, and $8: 1$. Therefore, the ratio of $6: 1(\mathrm{v} / \mathrm{v})$ was identified as optimum for the substrate conversion yield at $30^{\circ} \mathrm{C}$ and 48 hours. The results 


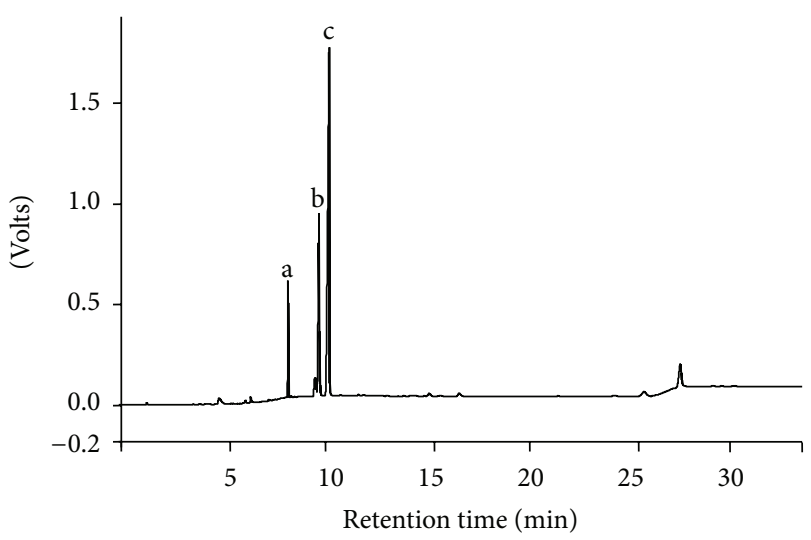

(a)

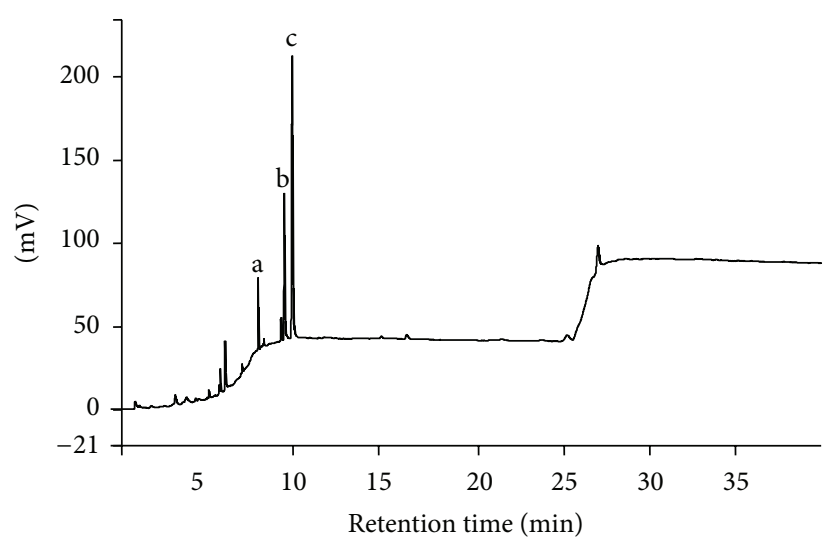

(b)

FIGURE 3: Gas chromatogram of fatty acid methyl esters formed in the transesterification reaction catalyzed by (a) chemical catalyst (alkali) and (b) silk-cocoon immobilized lipase. Methyl esters of a: palmitic acid (C 16:0), b: oleic acid (C 18:1), and c: linoleic acid (C 18:2).

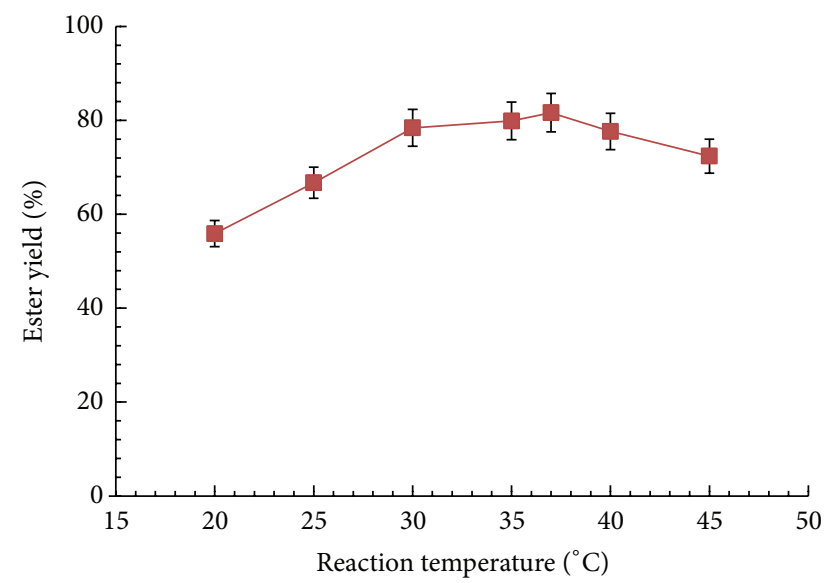

Figure 4: Effect of temperature on ester yields during the transesterification reaction catalyzed by the silk-cocoon immobilized lipase in a packed-bed bioreactor. Each datum point represents the average of the analysis of triplicate values represented by the error bars.

agreed to the other reports [31,32]. The transesterification reaction was carried out at different temperatures keeping 48 hours as reaction time and methanol: oil ratio at $6: 1$ $(\mathrm{v} / \mathrm{v})$. Initially, the ester yield was increased with increasing temperature starting from $20^{\circ} \mathrm{C}$. A maximum yield of $86 \%$ was achieved at $37^{\circ} \mathrm{C}$ (Figure 4).

The influence of temperature on the ester yield during immobilized lipase catalyzed transesterification reaction has been reported by others [33]. The thermal stability of the immobilized lipase was comparatively higher than the lipase in free form and at elevated temperature beyond $40^{\circ} \mathrm{C}$ the yield of the ester was declined.

3.5. Biodiesel Yield versus Reaction Time. The substrate conversion and the corresponding yield of the esters in the bioreactor were monitored at different reaction time intervals at $30^{\circ} \mathrm{C}$. The low reaction temperature $\left(30^{\circ} \mathrm{C}\right)$ was chosen to

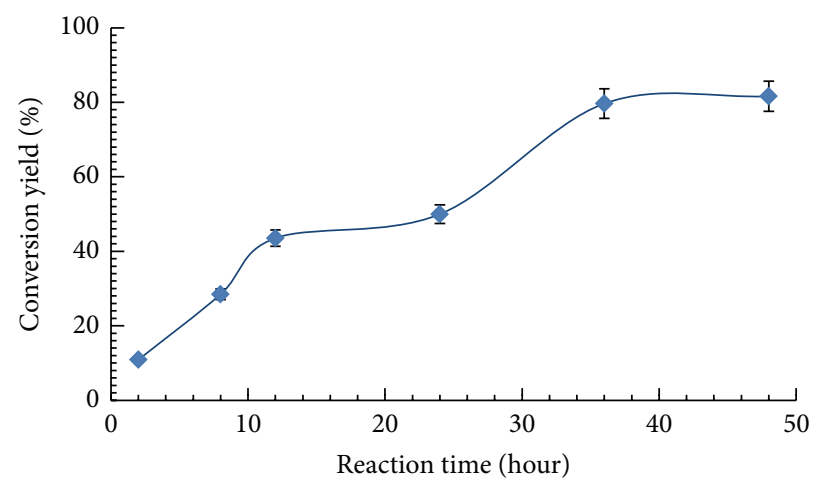

FIGURE 5: Variation in substrate conversion yields during transesterification in packed-bed bioreactor with the progress of reaction time at $30^{\circ} \mathrm{C}$. (Each datum point represents the average of the analysis of triplicate values represented by the error bars.)

prolong the stability of the enzyme and to reduce the energy consumption involved in the process.

The substrate conversion yield reached the stationery phase after 48 hours of the reaction time (Figure 5), where maximum conversion achieved was $81.62 \%$.

The reaction was investigated for the consecutive cycles using the same set of immobilized lipase keeping 48 hours of reaction time for each cycle (Figure 6). The substrate conversion was only marginally decreased till third cycle of the reaction since less than even $5 \%$ of the original activity was decreased in each of the second and third cycle. Nearly $60 \%$ of the original activity was retained in the fourth cycle. At the end of sixth cycle $\sim 37 \%$ of the original activity was retained.

The results demonstrated the high operational stability of the silk-cocoon immobilized lipase. The high operational stability of the immobilized lipase will lead to a high cumulative yield of the biodiesel after repeating the reaction at least up to the sixth reaction cycle. 


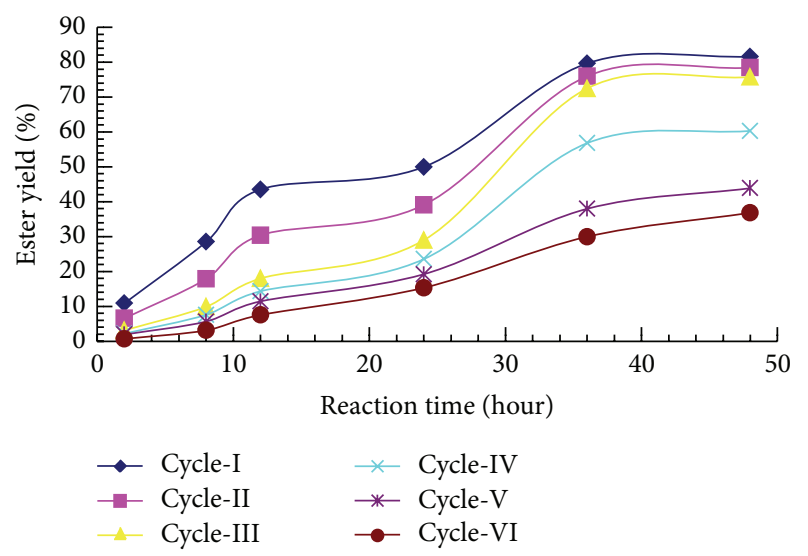

FIGURE 6: Operational stability of the silk-cocoon immobilized lipase carried out at $30^{\circ} \mathrm{C}$.

\section{Conclusions}

The silk-cocoon, a biodegradable and renewable biomaterial, is demonstrated as novel support matrix for the chemical immobilization of lipase. The cocoon matrix greatly enhanced the catalytic efficiency of the lipase by providing hydrophobic and porous microenvironment that facilitates diffusion of the nonpolar substrates to interact with the enzyme and promotes the reactions. A packed-bed bioreactor was successfully fabricated with the immobilized lipase for transesterification of sunflower oil for the production of biodiesel. The silk-cocoon matrix also offers high operational stability to the lipase and high biodiesel conversion yield, hence supporting the prospect of scaling up the process for industrial production of biodiesel.

\section{Conflict of Interests}

The authors declare that there is no conflict of interests regarding the publication of this paper.

\section{Acknowledgments}

The authors gratefully acknowledge Mr. Muksud Hussain for generously supplying the silk cocoon, Ms. Sharmin A. Hussain for her initial technical help, and Mr. Prasun Bhattacharjee for his technical support for the GC analysis. The equipment facilities supported by the Department of Chemical Engineering (for GC) and CIF (for FESEM), IIT Guwahati, are duly acknowledged.

\section{References}

[1] S. Shah, S. Sharma, and M. N. Gupta, "Biodiesel preparation by lipase-catalyzed transesterification of Jatropha oil," Energy and Fuels, vol. 18, no. 1, pp. 154-159, 2004.

[2] C.-J. Shieh, H.-F. Liao, and C.-C. Lee, "Optimization of lipasecatalyzed biodiesel by response surface methodology," Bioresource Technology, vol. 88, no. 2, pp. 103-106, 2003.
[3] Y. Yücel, "Biodiesel production from pomace oil by using lipase immobilized onto olive pomace," Bioresource Technology, vol. 102, no. 4, pp. 3977-3980, 2011.

[4] M. G. F. Denise, J. S. DeSousa, and E. D. A. C. Oliveira, "Biotechnological methods to produce biodiesel," in Biofuels, pp. 315-337, 2011.

[5] X. Wang, G. Zhou, H. Zhang, S. Du, Y. Xu, and C. Wang, "Immobilization and catalytic activity of lipase on mesoporous silica prepared from biocompatible gelatin organic template," Journal of Non-Crystalline Solids, vol. 357, no. 15, pp. 3027-3032, 2011.

[6] X.-J. Huang, P.-C. Chen, F. Huang, Y. Ou, M.-R. Chen, and Z.$\mathrm{K}$. Xu, "Immobilization of Candida rugosa lipase on electrospun cellulose nanofiber membrane," Journal of Molecular Catalysis $B$, vol. 70, no. 3-4, pp. 95-100, 2011.

[7] J. J. Karimpil, J. S. Melo, and S. F. D’Souza, "Hen egg white as a feeder protein for lipase immobilization," Journal of Molecular Catalysis B, vol. 71, no. 3-4, pp. 113-118, 2011.

[8] S. Gao, Y. Wang, X. Diao, G. Luo, and Y. Dai, "Effect of pore diameter and cross-linking method on the immobilization efficiency of Candida rugosa lipase in SBA-15," Bioresource Technology, vol. 101, no. 11, pp. 3830-3837, 2010.

[9] J. C. Moreno-Pirajàn and L. Giraldo, "Study of immobilized Candida rugosa lipase for biodiesel fuel production from palm oil by flow microcalorimetry," Arabian Journal of Chemistry, vol. 4, no. 1, pp. 55-62, 2011.

[10] H.-T. Deng, Z.-K. Xu, Z.-M. Liu, J. Wu, and P. Ye, "Adsorption immobilization of Candida rugosa lipases on polypropylene hollow fiber microfiltration membranes modified by hydrophobic polypeptides," Enzyme and Microbial Technology, vol. 35, no. 5, pp. 437-443, 2004.

[11] D. Y. C. Leung, X. Wu, and M. K. H. Leung, "A review on biodiesel production using catalyzed transesterification," Applied Energy, vol. 87, no. 4, pp. 1083-1095, 2010.

[12] M. Szczesna Antczak, A. Kubiak, T. Antczak, and S. Bielecki, "Enzymatic biodiesel synthesis-key factors affecting efficiency of the process," Renewable Energy, vol. 34, no. 5, pp. 1185-1194, 2009.

[13] A. Banerjee and R. Chakraborty, "Parametric sensitivity in transesterification of waste cooking oil for biodiesel production-a review," Resources, Conservation and Recycling, vol. 53, no. 9, pp. 490-497, 2009.

[14] A. Bajaj, P. Lohan, P. N. Jha, and R. Mehrotra, "Biodiesel production through lipase catalyzed transesterification: an overview," Journal of Molecular Catalysis B, vol. 62, no. 1, pp. 9-14, 2010.

[15] T. Tan, J. Lu, K. Nie, L. Deng, and F. Wang, "Biodiesel production with immobilized lipase: a review," Biotechnology Advances, vol. 28, no. 5, pp. 628-634, 2010.

[16] M. K. Lam, K. T. Lee, and A. R. Mohamed, "Homogeneous, heterogeneous and enzymatic catalysis for transesterification of high free fatty acid oil (waste cooking oil) to biodiesel: a review," Biotechnology Advances, vol. 28, no. 4, pp. 500-518, 2010.

[17] H.-T. Deng, Z.-K. Xu, Z.-W. Dai, J. Wu, and P. Seta, "Immobilization of Candida rugosa lipase on polypropylene microfiltration membrane modified by glycopolymer: hydrolysis of olive oil in biphasic bioreactor," Enzyme and Microbial Technology, vol. 36, no. 7, pp. 996-1002, 2005.

[18] X.-J. Huang, A.-G. Yu, and Z.-K. Xu, "Covalent immobilization of lipase from Candida rugosa onto poly(acrylonitrile-co-2hydroxyethyl methacrylate) electrospun fibrous membranes for potential bioreactor application," Bioresource Technology, vol. 99, no. 13, pp. 5459-5465, 2008. 
[19] A. Sánchez, J. L. Del Río, F. Valero, J. Lafuente, I. Faus, and C. Solà, "Continuous enantioselective esterification of trans-2phenyl-1- cyclohexanol using a new Candida rugosa lipase in a packed bed bioreactor," Journal of Biotechnology, vol. 84, no. 1, pp. 1-12, 2000.

[20] J. S. Mendes, J. S. Silva, A. L. O. Ferreira, and G. F. Silva, "Simulation of process interesterification in fluidized bed bioreactor for production of biodiesel," Computer Aided Chemical Engineering, vol. 27, pp. 1803-1808, 2009.

[21] A. Salihu, M. Z. Alam, M. I. Abdulkarim, and H. M. Salleh, "Effect of process parameters on lipase production by Candida cylindracea in stirred tank bioreactor using renewable palm oil mill effluent based medium," Journal of Molecular Catalysis B, vol. 72, no. 3-4, pp. 187-192, 2011.

[22] F. Ihara, Y. Kageyama, M. Hirata, T. Nihira, and Y. Yamada, "Purification, characterization, and molecular cloning of lactonizing lipase from Pseudomonas species," Journal of Biological Chemistry, vol. 266, no. 27, pp. 18135-18140, 1991.

[23] R. C. Rodrigues, G. Volpato, K. Wada, and M. A. Z. Ayub, "Enzymatic synthesis of biodiesel from transesterification reactions of vegetable oils and short chain alcohols," Journal of the American Oil Chemists' Society, vol. 85, no. 10, pp. 925-930, 2008.

[24] V. Kearns, A. C. MacIntosh, A. Crawford, and P. V. Hatton, "Silkbased biomaterialsfortissue engineering," in Topics in Tissue Engineering, pp. 1-19, 2008.

[25] C. Acharya, S. K. Ghosh, and S. C. Kundu, "Silk fibroin protein from mulberry and non-mulberry silkworms: cytotoxicity, biocompatibility and kinetics of L929 murine fibroblast adhesion," Journal of Materials Science, vol. 19, no. 8, pp. 2827-2836, 2008.

[26] S. Prasong, S. Wilaiwan, and S. Yaowalak, "Cross-section images of Eri (Samia ricini)-silk fibers and their secondary structures after treatment with different organic solvents," Journal of Biological Sciences, vol. 11, no. 1, pp. 46-51, 2011.

[27] S. J. Kline and F. A. McClintock, "Describing uncertainties in single-sample experiments," Mechanical Engineering, vol. 75, pp. 3-8, 1953.

[28] G. Antolín, F. V. Tinaut, Y. Briceo, V. Castao, C. Pérez, and A. I. Ramírez, "Optimisation of biodiesel production by sunflower oil transesterification," Bioresource Technology, vol. 83, no. 2, pp. 111-114, 2002.

[29] Y. M. Shashidhara, A. Naik, H. S. Srinivasa, and K. Chidambara, "Biodiesel oils for C.I engine operation and energy conservation," in Proceedings of the International Conference on Energy and Environmental Technologies for Sustainable Development, pp. 232-236, 2003.

[30] U. Rashid, F. Anwar, B. R. Moser, and S. Ashraf, "Production of sunflower oil methyl esters by optimized alkali-catalyzed methanolysis," Biomass and Bioenergy, vol. 32, no. 12, pp. 1202$1205,2008$.

[31] B. Freedman, E. H. Pryde, and T. L. Mounts, "Variables affecting the yields of fatty esters from transesterified vegetable oils," Journal of the American Oil Chemists Society, vol. 61, no. 10, pp. 1638-1643, 1984.

[32] A. C. Oliveira and M. F. Rosa, "Enzymatic transesterification of sunflower oil in an aqueous-oil biphasic system," Journal of the American Oil Chemists' Society, vol. 83, no. 1, pp. 21-25, 2006.

[33] R. García, M. Martínez, and J. Aracil, "Enzymatic esterification of an acid with an epoxide using an immobilized lipase from Mucor miehei as catalyst: optimization of the yield and isomeric excess of ester by statistical analysis," Journal of Industrial Microbiology and Biotechnology, vol. 28, no. 3, pp. 173-179, 2002. 

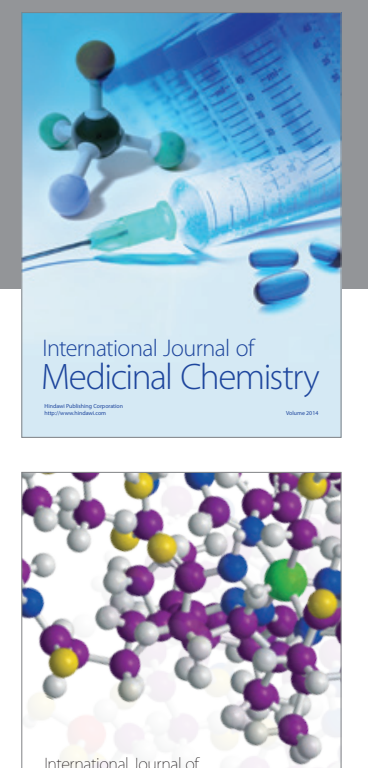

\section{Carbohydrate} Chemistry

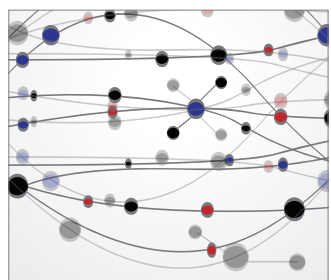

The Scientific World Journal
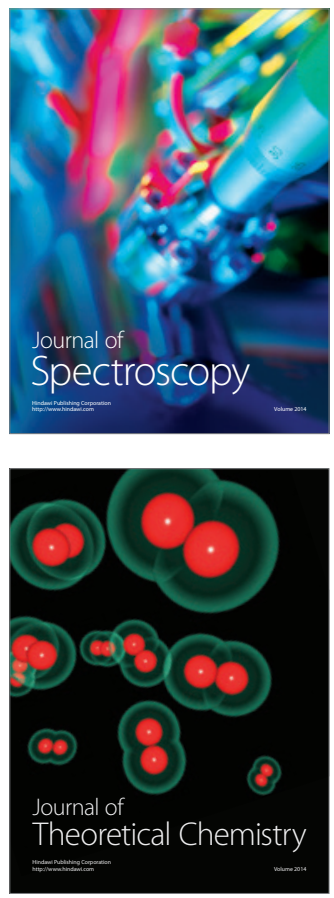
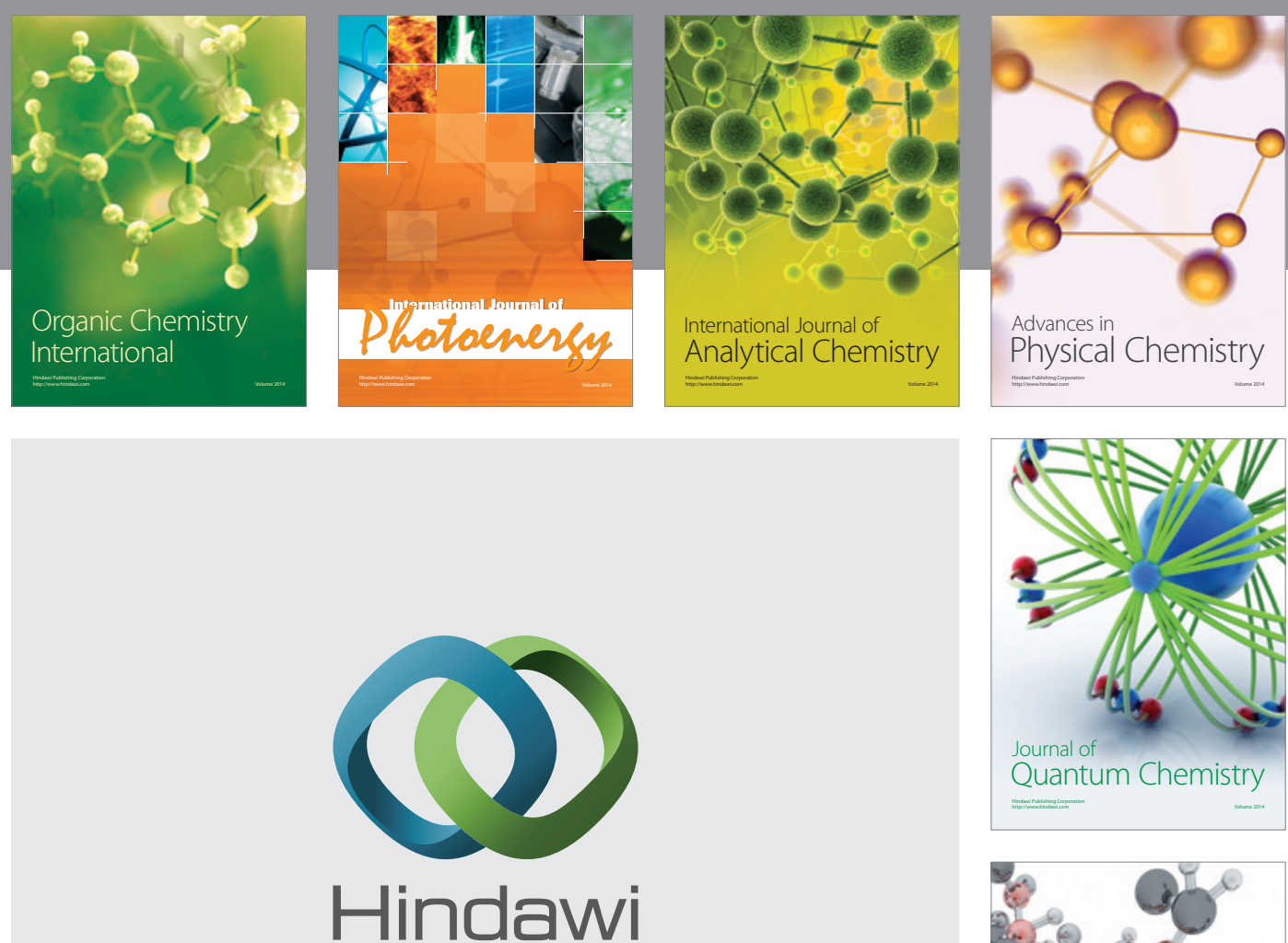

Submit your manuscripts at

http://www.hindawi.com

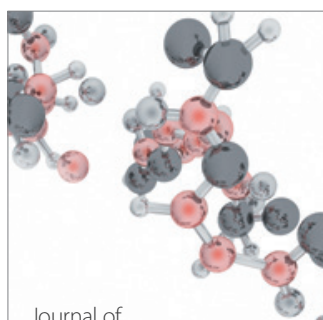

Analytical Methods

in Chemistry

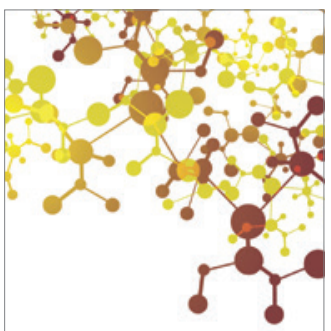

Journal of

Applied Chemistry

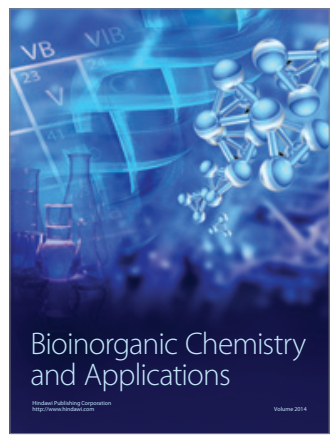

Inorganic Chemistry
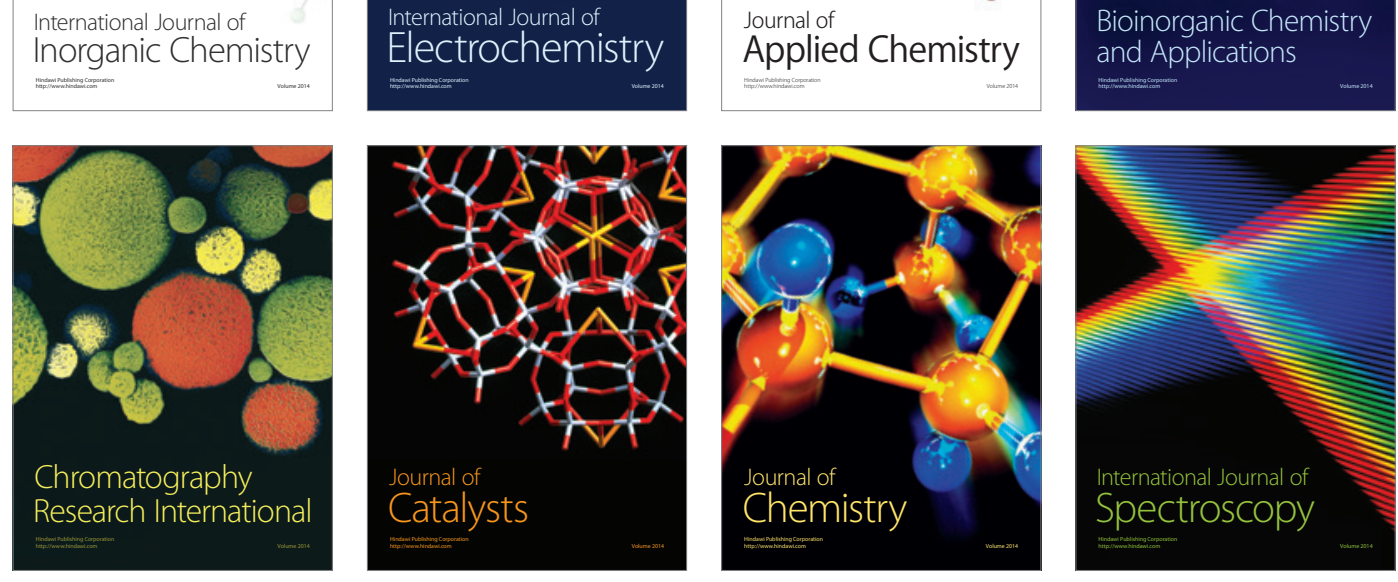